\title{
Keragaan Pertumbuhan dan Hasil Tanaman Berbasis Padi Gogo pada Lahan Kering di Maluku
}

\author{
Variation of Plant Growth and Yield Based on Upland Rice on Dry Land in Maluku
}

\author{
Irfan Ohorella, Sheny Kaihatu, Edwen D. Waas*
}

Balai Pengkajian Teknologi Pertanian (BPTP) Maluku, Jln. Chr. Soplanit Rumah Tiga, Ambon 97234

*E-mail Penulis Korespondensi: edwenwaas@gmail.com

\begin{abstract}
Upland rice-based cropping pattern is a form of multiple cropping including intercropping, sequential planting, and relay planting where upland rice as a base crop can be preceded and/or rotated with other food crops as a secondary crop. The research was aimed to provide recommendations for upland rice-based cropping pattern technology in dryland agroecosystems in Maluku that would be able to increase land productivity > 1.00 (MCI = Multiple Cropping Index > $100 \%$ ) compared to existing cropping patterns. The study used a Randomized Block Design (RCBD) with four treatments and repeated five times (farmers as replications). Four treatments for upland rice-based planting pattern technology assemblies, namely: 1) Pattern-A (Farmer A Pattern); 2) Pattern-B (Farmer B Planting Pattern B); 3) Pattern C (Farmer Improvement Cropping Pattern); and 4) Pattern D (Introduced Plant Pattern). The results showed that upland rice was planted double (multiple cropping) through intercropping and/or sequential cropping, namely Improved Cropping Patterns (Pattern C = Upland Rice + Corn - Peanuts) and Introducing Cropping Patterns (Pattern D = Upland Rice + Corn/Cassava - Green Beans - Peanuts) can increase land productivity with a double-cropping index $1.35-1.80$ (IPG = $135 \%$ - 180\%) compared to upland rice grown in monoculture (Farming Patterns). Multiple cropping (Upland Rice + Corn/Cassava - Green Beans - Peanuts) can be recommended as Upland Rice-Based Planting Technology Package on dry land in Maluku, because it can increase land productivity> 1.00 with an MCI (Multiple Cropping Index) of $180 \%$.
\end{abstract}

Keywords: dry land, performance, upland rice

\section{ABSTRAK}

Pola Tanam berbasis padi gogo merupakan bentuk pola bertanam ganda meliputi tumpangsari, tumpang gilir (runtun) dan tanaman sisipan dimana padi gogo sebagai komoditi pokok (base crop) yang bisa didahului dan atau digilir dengan tanaman pangan lainnya sebagai komoditi ikutan (secondary crop). Tujuan dari penelitian ini adalah untuk mendapatan rekomendasi paket teknologi pola tanam berbasis padi gogo pada agroekosistem lahan kering di Maluku yang mampu meningkatan produktivitas lahan > 1.00 (IPG = Indeks Pertanaman Ganda >100 \%) dibandingkan dengan pola tanam petani eksisting. Penelitian menggunakan Rancangan Acak Kelompok (RAK) dengan empat macam perlakuan dan diulang lima kali (petani sebagai ulangan). Empat perlakukan rakitan teknologi pola tanam berbasis padi gogo, yaitu: 1) Pola-A (Pola Tanam Petani A); 2) Pola-B (Pola Tanam Petani B); 3) Pola C (Pola Tanam Petani Perbaikan); dan 4) Pola D (Pola Tanaman Introduksi). Hasil penelitian menunjukkan bahwa padi gogo ditanam secara ganda (multiple cropping) melalui tumpangsari dan atau tumpanggilir, yaitu Pola Tanam Petani Perbaikan (Pola C $=\mathrm{Padi}$ Gogo + Jagung - Kacang Tanah) dan Pola Tanam Introduksi (Pola D = Padi Gogo + Jagung/Ubikayu - Kacang Hijau Kacang Tanah) dapat meningkatkan produktivitas lahan $1.35-1.80$ (IPG $=135 \%-180 \%)$ dibandingkan jika padi gogo ditanam secara monokultur (Pola Tanam Petani). Pola bertanam ganda (Padi Gogo+Jagung/Ubikayu - Kacang Hijau Kacang Tanah) dapat direkomendasikan sebagai Paket Teknologi Pola Tanam Berbasis Padi Gogo pada lahan kering di Maluku, karena dapat meningkatkan produktivitas lahan >1.00 dengan nilai IPG (Indeks Pertanaman Ganda) $180 \%$.

Kata Kunci: keragaan, lahan kering, padi gogo

\section{PENDAHULUAN}

Padi gogo adalah padi yang ditanam pada lahan kering yang sepanjang hidupnya tidak digenangi air dan sumber kebutuhan airnya berasal dari kelembaban tanah yang berasal dari curah hujan (Sumarno dan Hidayat, 2007). Produktivitas padi gogo pada tahun 2013 rata-rata 3,3 t/ha, di bawah produktivitas padi sawah yang mencapai 5,3 t/ha (Kementan 2014 dalam Hairmansis et al., 2016). Rendahnya hasil padi gogo disebabkan oleh 
masalah fisik dan biologis pada lahan kering, antara lain kekeringan, kemasaman tanah, keracunan $\mathrm{Al}$ dan kesuburan tanah yang rendah (Fagi et al., 2004; Toha et al., 2009; Toha, 2012; Rochayati dan Dariah 2012 dalam Hairmansis et al., 2016). Padi gogo masih dibudidayakan secara subsisten dengan input rendah (Toha, 2012). Padi gogo biasa ditanam secara tugal pada lahan terbuka, daerah aliran sungai (DAS), atau tumpang sari dengan tanaman pangan ataupun tanaman perkebunan muda.

Saat ini petani padi gogo masih sulit mendapatkan varietas unggul bermutu sehingga petani tidak dapat mengelola usahataninya sebagaimana yang diharapkan, termasuk menerapkan teknologi yang dianjurkan. Semakin berkurangnya lahan sawah karena alih fungsi lahan, maka pengembangan dan peningkatan produksi pangan diarahkan dengan memanfaatkan lahan kering. Lahan kering merupakan salah satu sumber daya lahan yang mempunyai potensi besar untuk dimanfaatkan sebagai sumber pangan (Nazirah dan Damanik, 2015). Fitria dan Ali (2014) mengatakan bahwa lahan kering dapat dimanfaatkan untuk ekstensifikasi padi dengan mengembangkan budidaya padi gogo.

Potensi ketersediaan lahan untuk pengembangan pertanian lahan kering (termasuk padi gogo) di Maluku tercatat sekitar 847.601 ha terdiri atas wanatani (129.136 ha) dengan kemiringan lereng 9-15\% dan dataran rendah (718.465 ha) dengan kemiringan lereng 3-8\% (Susanto dan Bustaman, 2006), namun yang digunakan hanya sebagian kecil saja $305.136,40$ ha (36\%), sehingga peluang pengembangan secara ekstensifikasi masih terbuka luas yaitu 542.464,64 ha atau sekitar $64 \%$ dari lahan potensial. Berdasarkan data BPS Promal (2016), rataan produktivitas padi gogo selama lima tahun terakhir (2011-2015) di Maluku masih tergolong rendah (2,73 t/ha) sedangkan potensi hasil dapat mencapai 7,0 t/ha dengan penerapan teknologi inovatif.

Relatif masih rendahnya produktivitas padi dalam usahatani padi gogo ini, antara lain karena petani di Maluku belum sepenuhnya menerapkan teknologi budidaya inovatif, ditandai dengan penggunaan benih padi bermutu rendah dan berumur panjang (> 130 hari). Pembukaan lahan menggunakan sistem TBT (tebangbakar-tanam), penanaman dilakukan berdasarkan prinsip TOT (tanpa olah tanah) dan tidak melakukan pemupukan serta pengendalian OPT, kecuali pengendalian gulma (penyiangan). Indeks Pertanaman Ganda (IPG) yang kurang dari $100 \%$, karena umumnya pemanfaatan lahan kering dengan tanaman pangan dilakukan satu kali tanam/tahun.

Berdasarkan rataan luas panen padi (padi sawah dan pagi gogo) di Maluku selama lima tahun terakhir (2011-2015), yaitu seluas 21.774,20 ha dengan total produksi 98.825,08 ton GKG atau setara dengan 59.295 ton beras (BPS Promal, 2016). Produksi ini belum mencukupi kebutuhan beras daerah Maluku sebesar 75 ton beras/tahun, sehingga pemerintah daerah terpaksa mengimpor beras dari luar daerah (Makasar dan Surabaya) sekitar 15.000 ton beras/tahun. Jika lahan kering potensial seluas 542.464,64 ha (Susanto dan Bustaman, 2006) dikembangkan sekitar 20\% saja dengan produktivitas $2.73 \mathrm{t} / \mathrm{ha}$, maka produksi padi gogo bisa mencapai 54.246,46 ton atau setara dengan 32.548 ton beras (swasembada pangan di Maluku tercapai).

Di Maluku, padi gogo diusahakan pada agroekosistem lahan kering iklim kering (kabupaten Maluku Tengara, kota Tual, Maluku Tenggara Barat dan Maluku Barat Daya) dan iklim basah (Maluku Tengah, Seram Bagian Barat, Seram Bagian Timur, Buru, dan Buru Selatan). Pola tanam yang umum dilaksanakan adalah: Padi Gogo-Kacang Tanah/Kedelai-Bero dan atau Jagung-Kacang Tanah/Kedelai-Bero. Padi gogo dan jagung biasanya ditanam pada musim hujan, sedangkan kacang tanah dan kedelai ditanam akhir musim hujan atau awal musim kemarau.

Kondisi iklim Indonesia (CH 100 mm-200 mm) dengan lama periode tanam lebih dari 10 bulan mencapai $75 \%$, maka secara teori dapat diusahakan 2-3 kali pertanaman setahun dengan pola tanam: padi gogo + jagung + ubi kayu - kacang tanah/kedelai - kacang hijau/kacang tunggak/kacang uji (Sumarno dan Hidayat, 2007). Sedangkan di Maluku lama periode tanam kurang dari 10 bulan, sehingga hanya bisa diusahakan 1-2 kali tanam dengan masa bero 1 kali, tetapi bisa diusahakan tanaman kacang hijau berumur genjah dan tidak banyak memerlukan air. Pengaturan pola tanam intensif tersebut dapat mencapai setara gabah di atas 20 ton/ha/tahun dengan kisaran 9,3 ton-23,2 ton/ha/tahun, sedangkan pola petani (padi gogo + jagung + ubi kayu - kacang tanah) hanya berkisar antara 2,3 ton sampai 11,2 ton/ha/tahun (CRIFC 1986; Arifin dan Toha, 1996).

Penelitian ini bertujuan untuk mendapatkan rekomendasi paket teknologi pola tanam berbasis padi gogo pada agroekosistem lahan kering di Maluku yang mampu meningkatan produktivitas lahan $>1.00(\mathrm{IPG}=$ Indeks Pertanaman Ganda > $100 \%$ ) dibandingkan dengan usahatani petani eksisting.

\section{METODOLOGI}

Kajian keragaan pertumbuhan dan hasil tanaman berbasis padi gogo pada lahan kering di Maluku dilaksanakan di kabupaten Maluku Tenggara Barat, Maret-Desember 2017. Lokasi kajian tergolong agroekosistem lahan kering dataran rendah iklim kering dan berdasarkan klasifikasi agroklimate masuk dalam zone II.3 dengan curah hujan 1500 - $1800 \mathrm{~mm}$, tercakup zona D3 (Oldeman) dengan bulan basah 3-4 bulan dan bulan kering 4-6 bulan. Kajian menggunakan Rancangan Acak Kelompok yang diulang lima kali (petani sebagai ulangan), dengan empat perlakuan sehingga memenuhi kaidah penelitian adaptif $(\mathrm{t}-1)(\mathrm{n}-1) \geq 11$ (Badan Litbang Pertanian, 2005). Keempat perlakuan tersebut mencakup dua pola tanam petani (eksisting), satu pola petani yang diperbaiki, dan satu pola tanam introduksi. Rancangan kajian disesuaikan dengan distribusi curah hujan (Gambar 1). 


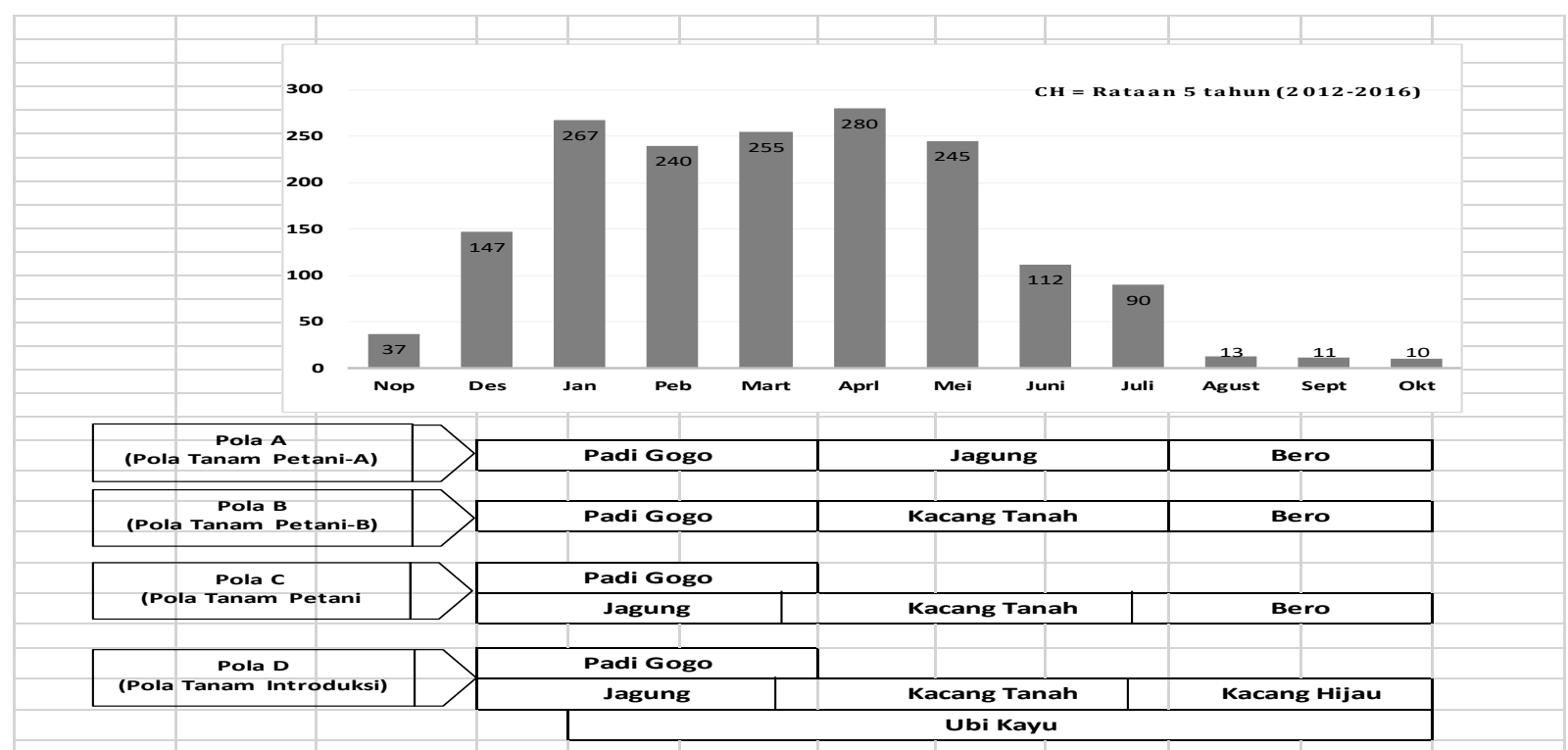

Gambar 1.Rancangan penelitian pola tanam berbasis padi gogo menurut distribusi curah hujan di Kecamatan Saumlaki, Kabupaten Maluku Tenggara Barat, MT 2017 berikut:

Rincian pola tanam padi gogo yang dikaji sebagai

Pola A (Pola tanam petani-A):

\section{Padi gogo - Jagung - Bero}

Padi gogo lokal Tanimbar Merah (umur panen 90 hari) ditanam secara monokultur, jarak tanam tidak teratur (acak). Setelah padi gogo dipanen, jagung lokal Pulut Tanimbar ditanam secara monokultur dengan jarak tanam $100 \mathrm{~cm} \times 100 \mathrm{~cm}$, kemudian lahan dibiarkan kosong tidak ditanami (diberokan). Pemupukan padi gogo dilakukan secara larikan dengan dosis pupuk 100 $\mathrm{kg}$ phonska/ha + pupuk pelengkap cair Bio-88 (16 L/ha), sedangkan jagung dipupuk dengan dosis pemupukan 200 $\mathrm{kg}$ phonska/ha + pupuk pelengkap cair Bio-88 (16 L/ha). Sebelum olah tanah, dilakukan pemberian herbisida Roundup (4 L/ha). Tidak ada pengendalian hama dan penyakit, baik pada padi gogo maupun jagung.

Pola B (Pola tanam petani-B):

\section{Padi gogo - Kacang Tanah - Bero}

Padi gogo Lokal Tanimbar Merah ditanam secara monokultur jarak tanam tidak teratur, setelah panen padi, kacang tanah Lokal Merah ditanam secara monokultur jarak tanam $40 \mathrm{~cm} \times 40 \mathrm{~cm}$, setelah itu dibiarkan kosong tidak ditanami (diberokan). Pemupukan padi gogo sama dengan Pola A, sedangkan kacang tanah tidak diberi pupuk. Sebelum olah tanah dilakukan pemberian herbisida Roundup (4 L/ha). Pengendalian hama penyakit tidak dilakukan, baik pada padi gogo maupun kacang tanah.

Pola C (Pola tanam petani perbaikan):

Padi gogo+jagung - Kacang Tanah - Bero

Perbaikan yang dilakukan terhadap pola petani adalah menerapkan pola bertanam ganda dan pengaturan jarak tanam (populasi tanaman). Padi gogo varietas Inpago 10 (umur $115 \mathrm{hst}$ ) ditanam dengan jarak $50 \mathrm{~cm} \times$
$10 \mathrm{~cm}$ (populasi $74 \%$ ) ditumpangsarikan dengan jagung varietas Srikandi Kuning (umur $110 \mathrm{hst}$ ) jarak tanam 400 $\mathrm{cm} \times(75 \mathrm{~cm} \times 40 \mathrm{~cm})$, populasi $48 \%$. Setelah padi gogo dan jagung dipanen, kacang tanah varietas Lokal Merah ditanam secara monokultur, jarak tanam $40 \mathrm{~cm} \times 20 \mathrm{~cm}$. Setelah kacang tanah dipanen, lahan diberokan (tidak ditanami). Pemupukan padi gogo dilakukan secara larikan dan jagung secara tugal dengan dosis masingmasing $200 \mathrm{~kg}$ phonska/ha + Pupuk Organik Cair Supermes $(8 \mathrm{~L} / \mathrm{ha})$, disesuaikan dengan populasi tanaman (padi gogo 74\% dan Jagung 48\%). Sedangkan kacang tanah (populasi 100\%), dipupuk dengan $100 \mathrm{~kg}$ phonska/ha + pupuk organik cair Supermes (8 L/ha). Untuk padi gogo pengendalian hama dilakukan dengan pemberian Furadan 3G (30 kg/ha/aplikasi) saat pemupukan dasar (10 hst) dan pemupukan susulan (30 hst), kemudian diikuti pemberian insektisida Baycarb (2 cc/L air) apabila ada serangan. Pengendalian hama penggerek batang jagung dilakukan dengan pemberian Furadan $3 \mathrm{G}$ melalui pucuk (30 kg/ha/aplikasi) pada umur 21 hst dan 42 hst. Pengendalian hama kacang tanah dengan secara pemantauan (pemberian insektisida apabila ada gejala serangan hama), dengan insektisida Baycarb (2 cc/L air).

Pola D (Pola tanam introduksi):

\section{Padi gogo+jagung/ubi kayu - Kacang Tanah -}

\section{Kacang Hijau}

Padi gogo varietas Inpago 10 ditanam dengan sistem tanam legowo $4: 1(50 \mathrm{~cm} \times(25 \mathrm{~cm} \times 12.5 \mathrm{~cm})$, populasi $80 \%$ ditumpangsarikan dengan jagung varietas Srikandi Kuning berbaris ganda, jarak tanam $400 \mathrm{~cm} \times$ $(75 \mathrm{~cm} \times 40 \mathrm{~cm})$, populasi $48 \%$. Tiga minggu kemudian disisip ubikayu dalam barisan jagung dengan jarak tanam $400 \mathrm{~cm} \times(75 \mathrm{~cm} \times 80 \mathrm{~cm})$, populasi $48 \%$. Setelah padi gogo dan jagung dipanen, kacang tanah varietas lokal 
Merah ditanam dengan jarak tanam $40 \mathrm{~cm} \times 20 \mathrm{~cm}$, populasi $56 \%$. Setelah kacang tanah dipanen, kacang hijau varietas Vima-1 ditanam, jarak tanam $40 \mathrm{~cm} \times 20$ $\mathrm{cm}$, populasi $56 \%$. Pemupukan padi gogo dan jagung dilakukan secara larikan, dengan dosis $200 \mathrm{~kg}$ phonska/ha + Pupuk Organik Cair Supermes (8 lt/ha), disesuaikan dengan populasi tanaman masing-masing. Sedangkan kacang tanah dan kacaang hijau dipupuk dengan dosis $100 \mathrm{~kg}$ phonska/ha + pupuk organik cair Supermes (8 L/ha). Hama padi gogo dikendalikan dengan pemberian Furadan $3 \mathrm{G}$ (30 kg/ha/aplikasi) saat pemupukan dasar (10 hst) dan pemupukan susulan (30 hst), kemudian diikuti pemberian insektisida Baycarb (2 cc/L air) apabila ada serangan. Untuk hama penggerek batang jagung dilakukan pengendalian dengan memberikan Furadan $3 \mathrm{G}$ melalui pucuk tanaman (30 kg/ha/aplikasi) pada 21 hst dan 42 hst. Pengendalian hama kacang tanah dan kacang hijau berdasarkan pemantauan (apabila ada gejala serangan hama pada kacang tanah diberikan insektisida Baycarb (2 cc/L air). Sedangkan pengendalian hama kacang hijau fase vegetatif diberikan insektisida Baycarb $(2 \mathrm{cc} / \mathrm{L}$ air $)$ dan menjelang pembungaan diberikan insektisida Decis $(0,5$ L/ha).

Parameter yang diamati meliputi: 1) komponen pertumbuhan (tinggi tanaman saat panen dan jumlah anakan (maksimum dan produktif); 2) komponen hasil (panjang malai, jumlah gabah berisi per malai, persentase gabah hampa per malai, jumlah gabah isi, jumlah gabah hampa, bobot gabah kering panen per rumpun, bobot 1.000 biji kering); 3) hasil gabah kering panen per petak panen (konversi ke hektar).

Peubah komponen pertumbuhan dan komponen hasil diamati terhadap 10 tanaman contoh per petak yang ditentukan secara acak, sedangkan hasil gabah kering panen dan pengamatan hama diamati pada petak contoh (ubinan) dengan ukuran 4,2 $\mathrm{m} \times 5,4 \mathrm{~m}=22,68 \mathrm{~m}^{2}$.

Analisis data perlakuan pola tanam berbasis padi gogo, meliputi:

(1) Aspek teknis agronomis (pertumbuhan, komponen hasil dan hasil) akan dianalisis menggunakan Anova/Sidik Ragam (Uji-F) untuk mengetahui pengaruh perlakuan dan uji lanjutan dengan Uji DMRT (Duncan Multiple Range Test) untuk mengetahui perbedaan pengaruh perlakuan dengan tingkat kepercayaan $95 \%$ mengikuti prosedur Gomez dan Gomez (1995).

(2) Untuk mengungkap produktivitas lahan akan dianalisis menggunakan Indeks Pertanaman Ganda (IPG) mengikuti cara yang dilakukan Palaniappan (1985) dan Wang and Li (2003). Formula yang digunakan adalah:

$$
\begin{aligned}
& \left.\mathrm{IPG}=\left(\Sigma A_{i}\right) / A_{j}\right) \times 100 \% \\
& \mathrm{i}=1
\end{aligned}
$$

dimana: IPG $=$ Indeks Pertanaman Ganda $=$ Multiple Cropping Index (MCI); $\mathrm{N}=$ Total jumah tanaman; $A_{i}=$ Luas lahan yang dipakai oleh tanaman ke-i dalam satu tahun; $A_{j}=$ Total luas lahan yang tersedia untuk penanaman.

\section{HASIL DAN PEMBAHASAN}

\section{Keragaan Pertumbuhan dan Hasil Tanaman Pola Tanam Berbasis Padi Gogo}

\section{a. Keragaan Pertumbuhan Tanaman Padi Gogo (Tanaman Urutan I)}

Tanaman padi gogo ditanam secara monokultur (Pola A = Padi Gogo - Jagung; dan Pola B=Padi Gogo Kacang Tanah) dan secara tumpangsari (Pola C $=$ Padi + Jagung - Kacang Hijau - Bero $)$ dan Pola D = (Padi Gogo + Jagung/Ubikayu - Kacang Hijau - Kacang Tanah).

Peubah komponen pertumbuhan Padi Gogo (tanaman urutan I) yang diamati dapat dilihat pada Tabel 1 yang menunjukkan bahwa tidak terdapat perbedaan antara Pola A maupun Pola B yang menggunakan varietas lokal Tanimbar Merah dengan Pola C dan Pola D yang menggunakan varietas unggul baru Inpago 10 terhadap persentase tumbuh. Persentase tumbuh berkisar antara $80,50-82,29 \%$. Hal ini berarti benih yang digunakan tergolong bermutu dan memiliki daya tumbuh yang baik. Varietas lokal mempunyai daya adaptasi yang sudah sesuai bagi kondisi lingkungan tempat tumbuhnya. Keunggulan padi gogo variates lokal adalah tahan kekeringan, rasa nasinya disukai masyarakat, harga jual berasnya lebih mahal, dan biaya saprodi rendah (Wahdah et al., 2012). Rendahnya produktivitas padi gogo karena penggunaan benih kultivar lokal yang daya hasilnya rendah (Hasfiah et al., 2012).

Untuk parameter tinggi tanaman, Pola A dan Pola B lebih tinggi $(96,84 \mathrm{~cm}$ dan $97,46 \mathrm{~cm})$ dari Pola $C$ dan Pola D $(83,50 \mathrm{~cm}$ dan $84,40 \mathrm{~cm})$. Hal ini disebabkan oleh pengaruh perangkat pembawa sifat yang di sebut gen. walaupun perangkat dasar penyusunnya sama tetapi pada setiap varietas memiliki tingkat keragaman genetik yang berbeda beda, baik tingkat genetik dalam tinggi tanaman, produksi tanaman dan sebagainya, sehingga menyebabkan variasi antar individu sesuai dengan pendapat Gadner et al. (1991); Wendi et al. (2014) bahwa masing-masing varietas tanaman dipengaruhi oleh genetiknya termasuk tinggi tanaman. Berkaitan dengan tinggi tanaman, petani lebih menyukai tanaman dengan tinggi tanaman yang tidak terlalu tinggi, hal ini berkaitan dengan tingkat ketahanan tanaman terhadap keadaan cuaca seperti hujan dan angin, dimana tanaman dengan tinggi tanaman lebih tinggi biasanya mudah rebah.

Menurut Sugiantari et al. (2017), daya kecambah secara umum memenuhi standar mutu benih international seed testing association (ISTA) kecambah normal tumbuh lebih besar dari $80 \%$ termasuk dalam kriteria mutu benih yang baik. Jumlah anakan maksimum dan jumlah anakan produktif pola A dan Pola B nyata lebih rendah (14,91 dan 14,56) dibandingkan dengan pada Pola C dan Pola D (21,96 dan 21,86). 
Tabel 1. Rataan komponen pertumbuhan tanaman padi gogo (tanaman urutan I) pada berbagai pola tanam berbasis padi gogo, Maluku Tenggara Barat, MK 2017

\begin{tabular}{llccccc}
\hline \multicolumn{1}{c}{ Pola Tanam } & Varietas & \multicolumn{5}{c}{ Komponen Pertumbuhan } \\
\cline { 3 - 7 } & & $\begin{array}{c}\text { Persen } \\
\text { Tumbu } \\
\end{array}$ & $\begin{array}{c}\text { Tinggi } \\
\text { Tnm }(\%) \\
(\mathrm{cm})\end{array}$ & $\begin{array}{c}\text { Jmlh } \\
\text { anakan } \\
\text { max }\end{array}$ & $\begin{array}{c}\text { Pmbentuka } \\
\text { n anakan } \\
\text { produktif } \\
(\%)\end{array}$ & $\begin{array}{c}\text { Jmlh anakan } \\
\text { produktif }\end{array}$ \\
\hline Pola A (Pola petani A) & Tanimbar merah & $80,50 \mathrm{a}$ & $96,84 \mathrm{a}$ & $14,91 \mathrm{~b}$ & $78,97 \mathrm{~b}$ & $11,50 \mathrm{~b}$ \\
Pola B (Pola petani B) & Tanimbar merah & $81,13 \mathrm{a}$ & $97,46 \mathrm{a}$ & $14,56 \mathrm{~b}$ & $79,33 \mathrm{~b}$ & $11,44 \mathrm{~b}$ \\
Pola C (Pola Petani Perbaikan) & Inpago 10 & $82,29 \mathrm{a}$ & $83,50 \mathrm{~b}$ & $21,96 \mathrm{a}$ & $68,29 \mathrm{a}$ & $14,94 \mathrm{a}$ \\
Pola D (Pola Introduksi) & Inpago 10 & $81,33 \mathrm{a}$ & $84,40 \mathrm{~b}$ & $21,86 \mathrm{a}$ & $69,13 \mathrm{a}$ & $15,11 \mathrm{a}$ \\
\hline Ratan & & 81,34 & 90,55 & 18,32 & 73,93 & 13,25 \\
\hline KK & & 16,24 & 10,09 & 7,23 & 10,88 & 3,23 \\
\hline
\end{tabular}

Keterangan: Angka rata-rata yang diikuti huruf yang sama pada kolom yang sama tidak berbeda nyata pada tingkat kepercayaan $95 \%$, Uji DMRT.

Tabel 2. Rataan komponen hasil dan hasil tanaman padi gogo (tanaman urutan I) pada berbagai pola tanam berbasis padi gogo, Maluku Tenggara Barat, MK 2017

\begin{tabular}{|c|c|c|c|c|c|c|}
\hline \multirow[b]{2}{*}{ Pola Tanam } & \multirow[b]{2}{*}{ Varietas } & \multicolumn{5}{|c|}{ Komponen Hasil dan Hasil } \\
\hline & & $\begin{array}{c}\text { Panjang } \\
\text { Malai } \\
(\mathrm{cm})\end{array}$ & $\begin{array}{c}\text { Gabah } \\
\text { Isi/malai }\end{array}$ & $\begin{array}{c}\text { Gabah } \\
\text { hampa } \\
(\%)\end{array}$ & $\begin{array}{c}\text { Bobot } \\
1000 \text { butir } \\
(\mathrm{g})\end{array}$ & $\begin{array}{c}\text { Hasil } \\
(\mathrm{GKG} / \mathrm{ha})\end{array}$ \\
\hline Pola A (Pola petani A) & Tanimbar merah & $20,64 a$ & $37,40 \mathrm{~b}$ & $43,31 \mathrm{a}$ & $23,94 \mathrm{a}$ & $2,04 \mathrm{a}$ \\
\hline Pola B (Pola petani B) & Tanimbar merah & $21,54 \mathrm{a}$ & $36,54 b$ & $43,14 \mathrm{a}$ & $24,04 \mathrm{a}$ & $1,85 \mathrm{a}$ \\
\hline Pola C (Pola Petani Perbaikan) & Inpago 10 & $19,85 b$ & $59,07 \mathrm{a}$ & $32,78 b$ & $24,33 a$ & $1,35 \mathrm{c}$ \\
\hline Pola D (Pola Introduksi) & Inpago 10 & $19,25 b$ & $63,96 a$ & $32,65 \mathrm{~b}$ & $24,35 \mathrm{a}$ & $1,59 \mathrm{~b}$ \\
\hline Rataan & & 20,32 & 11,70 & 49,24 & 37,97 & 24,16 \\
\hline KK & & 7,59 & 4,62 & 10,21 & 15,40 & 2,61 \\
\hline
\end{tabular}

Keterangan: Angka rata-rata yang diikuti huruf yang sama pada kolom yang sama tidak berbeda nyata pada tingkat kepercayaan $95 \%$, Uji DMRT.

Hal ini disebabkan karena perbedaan penggunaan varietas, namun persentase pembentukan anakan produktif Pola A dan Pola B memiliki perbedaan nyata lebih tinggi dibandingkan dengan Pola $\mathrm{C}$ dan Pola D (Tabel 1) tetapi menghasilkan jumlah anakan produktif yang rendah $(11,50$ dan 11,44) dibandingkan dengan Pola C dan Pola D (14,94 dan 15,11). Menurut Wagiyana et al. (2009); Donggulo et al. (2017) jumlah anakan produktif ditentukan oleh jumlah anakan yang tumbuh sebelum mencapai fase primordial, namun kemungkinan ada peluang bahwa anakan yang membentuk malai terakhir bisa saja tidak akan menghasilkan malai yang bulir-bulirnya terisi penuh semuanya, sehingga berpeluang menghasilkan gabah hampa.

Komponen hasil tanaman urutan I (padi gogo) dapat dilihat pada Tabel 2. Pada Tabel 2 terlihat bahwa perlakuan pola tanam berbasis padi gogo memberi pengaruh nyata terhadap komponen hasil tanaman padi gogo (tanaman urutan I). Pola tanam petani (Pola A dan Pola B) yang menggunakan varietas unggul lokal Tanimbar Merah memiliki panjang malai nyata lebih tinggi $(20,64 \mathrm{~cm}$ dan $21,54 \mathrm{~cm})$, namun jumlah gabah berisi per malai nyata lebih rendah $(37,40$ dan 36,54$)$ dibandingkan (Pola $\mathrm{C}$ dan Pola D) yang menggunakan varietas unggul baru Inpago 10 (59,07 dan 63,96).
Demikian juga Pola A dan Pola B memiliki persentase gabah hampa per malai nyata lebih tinggi $(43,14$ dan 43,31) di banding Pola C dan Pola D, sedangkan perlakuan pola tanam berbasis padi gogo (pola monokultur dan pola tumpangsari) tidak memberikan pengaruh nyata terhadap bobot 1000 butir dengan bobot antara 23,94-24,35 g. Pola A dan Pola B memberikan bobot 1000 butir cenderung lebih rendah dibandingkan Pola C dan Pola D. Tabel 2 juga menunjukkan bahwa pola tanam berbasis padi gogo memberikan pengaruh nyata terhadap hasil GKG per hektar. Rataan hasil yang dicapai pada penelitian ini masih tergolong rendah $(1,87$ t/ha), sedang potensi hasil khusus padi gogo varietas Inpago 10 dapat mencapai 7,3 t/ha. Rendahnya hasil disebabkan serangan burung pada lokasi penelitian cukup tinggi, karena di BBU (Balai Benih Utama) Wesawak hanya ditanami pagi gogo ( \pm 1 ha), sedangkan lahan sisa ditanami sayuran, jagung dan ubi-ubian. Pola tanam petani (Pola A dan Pola B) yang ditanam secara monokultur menggunakan varietas lokal Tanimbar Merah memberikan hasil GKG per hektar nyata lebih tinggi $(2,041 \mathrm{t} / \mathrm{ha}$ dihasilkan pola $\mathrm{A}$ dan $1,825 \mathrm{t} / \mathrm{ha}$ dihasilkan pola B) dibandingkan dengan Pola C dan Pola D yang ditanam secara tumpangsari menggunakan varietas unggul baru Inpago 10. 
Tabel 3. Rataan komponen pertumbuhan, komponen hasil, dan hasil tanaman jagung tanaman urutan I dan II pada berbagai pola tanam berbasis padi gogo, Maluku Tenggara Barat, MK 2017

\begin{tabular}{|c|c|c|c|c|c|}
\hline \multirow[b]{2}{*}{ No } & \multirow[b]{2}{*}{ Parameter Pengamatan Jagung } & Pola-A & Pola-C & Pola-D & \multirow[t]{2}{*}{ Rataan VUB**) } \\
\hline & & $\begin{array}{c}\text { Lokal } \\
\text { Tanimbar }\end{array}$ & \multicolumn{2}{|c|}{ Srikandi Kuning } & \\
\hline \multirow[t]{4}{*}{ I } & Komponen Pertumbuhan & & & & \\
\hline & 1. Persentase tumbuh $(\%)$ & 93,75 & 85,50 & 84,80 & 85,15 \\
\hline & Tinggi Tanaman $(\mathrm{cm})$ & 164,30 & 146,50 & 134,72 & 140,61 \\
\hline & Tinggi letak tongkol $(\mathrm{cm})$ & 82,40 & 63,28 & 60,38 & 61,83 \\
\hline \multirow[t]{5}{*}{ II } & Komponen Hasil & & & & \\
\hline & 4. Panjang tongkol $(\mathrm{cm})$ & 13,80 & 14,35 & 14,26 & 14,31 \\
\hline & Diameter tongkol $(\mathrm{cm})$ & 3,85 & 4,22 & 4,16 & 4,19 \\
\hline & Bobot biji kering/tongkol (g) & 117,50 & 197,34 & 154,11 & 175,73 \\
\hline & Bobot 1000 biji kering & 26,65 & 28,38 & 26,56 & 27,47 \\
\hline \multirow[t]{4}{*}{ III } & Hasil & & & & \\
\hline & $\begin{array}{l}\text { 8. Bobot biji pipilan kering/petak contoh } \\
\left.\left(\mathrm{g} / 22.68 \mathrm{~m}^{2}\right)^{* * *}\right)\end{array}$ & 7126,00 & 4914,76 & 4472,50 & 4693,63 \\
\hline & 9. Hasil biji pipilan kering (t/ha) & 3,142 & 2,167 & 1,972 & 2,070 \\
\hline & 10. Populasi tanaman jagung & 100 & 48 & 48 & \\
\hline
\end{tabular}

Keterangan: *) Lokal Tanimbar; **) VUB=Varietas Unggul Baru; ***) Ukuran Petak Ubinan 5,4 m $\times 4,2 \mathrm{~m}\left(22,68 \mathrm{~m}{ }^{2}\right)$

Rendahnya hasil yang dicapai pada Pola C dan Pola D (pola Tumpangsari) disebabkan karena rendahnya populasi tanaman padi gogo (Pola C populasi $74 \%$ dan Pola D populasi $89 \%$ ).

\section{b. Keragaan Pertumbuhan, Komponen Hasil, dan Hasil Tanaman Jagung (Tanaman Urutan I dan II)}

Peubah komponen pertumbuhan tanaman jagung yang diamati meliputi persentase tumbuh, tinggi tanaman, dan tinggi letak tongkol, tersaji pada Tabel 3 yang menunjukkan bahwa tanaman jagung Srikandi Kuning ditanam secara tumpangsari dengan padi gogo pada Pola-C memiliki persentase tumbuh, tinggi tanaman, dan tinggi letak tongkol lebih tinggi dibandingkan dengan Pola D. Jagung Srikandi Kuning (Pola Tumpangsari) bila dibandingkan dengan jagung varietas unggul lokal Tanimbar (Pola Monokultur) memiliki persentase tumbuh, tinggi tanaman dan tinggi letak tongkol lebih rendah. Tanaman jagung yang ditanam secara monokultur secara nyata mempunyai tinggi tanaman yang lebih besar karena tanaman memperoleh semua unsur hara yang dibutuhkan dengan baik. Jagung yang ditanam secara tumpangsari mengalami kompetisi dalam memperebutkan unsurunsur yang diperlukan untuk pertumbuhan tanaman (Permanasari dan Kastono, 2012). Rataan Tinggi tanaman jagung VUB Srikandi Kuning yang dicapai pada penelitian ini hanya $140,61 \mathrm{~cm}$ lebih rendah dibandingkan dengan deskripsinya yaitu $\pm 185 \mathrm{~cm}$ (Tamburian, 2012).

Peubah komponen hasil dan hasil tanaman jagung yang diamati meliputi panjang dan diameter tongkol, bobot biji kering per tongkol, bobot biji kering per petak ubinan, hasil biji pipilan kering per hektar, tersaji pada
Tabel 3. Tabel 3 menunjukkan bahwa tanaman jagung varietas unggul Srikandi Kuning yang ditanam secara tumpangsari (Pola-C dan Pola-D) memiliki persentase tumbuh dan pertumbuhan vegetatif lebih rendah, namun rata-rata komponen hasil lebih tinggi dibandingkan dengan jagung varietas unggul lokal Tanimbar monokultur (Pola A). Jagung Pola C memberikan komponen hasil dan hasil pipilan kering jagung lebih tinggi dibandingkan dengan Pola D. Pola C memberikan hasil biji pipilan kering per hektar cenderung lebih tinggi (2,167 t/ha) dibandingkan dengan Pola D, yaitu 1.972 t/ha (Tabel 3).

Selanjutnya Tabel 3 menunjukkan bahwa tanaman jagung ditanam secara tumpangsari (Pola-C dan Pola-D) rata-rata memberikan hasil biji pipilan kering lebih rendah (2.070 t/ha), jika dibandingkan dengan jagung monokultur (Pola A), yaitu 3,142 t/ha. Rendahnya hasil yang dicapai pada jagung yang ditanam secara tumpangsari (Pola C dan Pola D) karena populasi tanaman per hektar adalah rendah (48\%).

c. Keragaan Pertumbuhan, Komponen Hasil, dan Hasil Tanaman Kacang Tanah (Tanaman Urutan II dan III)

Peubah pertumbuhan, komponen hasil dan hasil tanaman kacang tanah sebagai tanaman urutan II (Pola-B dan Pola-C) dan tanaman urutan III (Pola-D) yang diamati meliputi tinggi tanaman, panjang dan jumlah polong berisi per tanaman, persentase polong muda, bobot 100 butir, bobot polong berisi per (tanaman dan petak ubinan) dan hasil polong kering per hektar, tersaji pada Tabel 4. Kacang tanah yang digunakan adalah verietas Lokal Merah, memiliki warna biji merah tua, rata-rata hasil di tingkat petani adalah sekitar 2,00 t/ha. Tanaman kacang tanah ditanam secara monokultur baik 
pada Pola-B dan Pola C (tanaman urutan II) memberikan pertumbuhan tanaman (tinggi tanaman) maupun komponen hasil (panjang dan jumlah polong per tanaman, bobot 100 butir, bobot polong berisi) lebih rendah, namun persentase polong muda per tanaman lebih tinggi dibandingkan jika ditanam secara tumpanggilir pada Pola-D, sebagai tanaman urutan III (Tabel 4). Idawanni et al. (2016) mengemukakan bahwa tinggi tanaman dipengaruhi oleh sifat genetik dan kondisi lingkungan tumbuh tanaman.

Selanjutnya Tabel 4 menunjukkan bahwa tanaman kacang tanah yang ditanam secara monokultur sebagai tanaman urutan II setelah padi gogo monokultur (Pola B) maupun setelah padi gogo tumpangsari dengan jagung (Pola $\mathrm{C}$ ) memberikan hasil polong kering per hektar tertinggi (berturut-turut $1.167 \mathrm{t}$ dan $1.187 \mathrm{t} / \mathrm{ha}$ ) dibandingkan jika ditanam secara monokultur (0.901 t/ha) sebagai tanaman urutan II setelah tumpangsari padi gogo dan jagung (Pola-D). Rendahnya hasil polong kering kacang tanah per hektar pada pola tanam tumpangsari disebabkan karena populasi tanaman rendah (56 \%) disamping pengaruh naungan ubikayu. Produktivitas tanaman (produksi per satuan luas) ditentukan oleh produksi per tanaman dan jumlah tanaman per satuan luas, terdapat kecenderungan bahwa semakin tinggi populasi per satuan luas, semakin tinggi produksi (Bunyamin dan Awaluddin, 2013). Hal ini didukung Siagian dan Harahap (2001), bahwa pertanaman rapat (populasi tinggi), evaporasi potensia (ETP) agak diperkecil, karena evaporasi dari permukaan tanah tertekan dan efisiensi penggunaan air diperbesar, sehingga produksi meningkat.

d. Keragaan Pertumbuhan, Komponen Hasil, dan Hasil Tanaman Kacang Hijau Tanaman Urutan II) Tanaman kacang hijau ditanam secara tumpangsari sebagai tanaman urutan II pada Pola-D = Pola Tanam Introduksi (Padi Gogo + Jagung/Ubikayu Kacang Hijau - Kacang Tanah, yaitu padi gogo ditumpangsarikan dengan jagung, tiga minggu kemudian tanaman ubikayu disisipkan didalam barisan jagung setiap dua tanaman jagung, setelah padi gogo dan jagung dipanen diikuti kacang tanah, dan setelah kacang tanah dipanen diikuti kacang hijau).

Tabel 4. Rataan komponen pertumbuhan, komponen hasil, dan hasil tanaman kacang tanah (tanaman urutan I dan III) pada berbagai pola tanam berbasis padi gogo, Maluku Tenggara Barat, MK 2017

\begin{tabular}{|c|c|c|c|c|c|}
\hline \multirow{2}{*}{ No } & \multirow{2}{*}{ Parameter Kacang Tanah } & \multicolumn{3}{|c|}{ Pola Tanam Berbasisi Padi Gogo } & \multirow{2}{*}{ Rataan } \\
\hline & & $\mathrm{B}$ & $\mathrm{C}$ & $\mathrm{D}$ & \\
\hline 1 & Persentase tumbuh (\%) & 96,65 & 96,50 & 96,75 & 96,63 \\
\hline 2 & Tinggi Tanaman $(\mathrm{cm})$ & 65,98 & 66,72 & 66,24 & 66,31 \\
\hline 3 & Panjang Polong $(\mathrm{cm})$ & 4,10 & 4,15 & 4,05 & 4,10 \\
\hline 4 & Jumlah polong isi/tanaman & 54,5 & 55,6 & 56,2 & 55,43 \\
\hline 5 & Polong muda/tanaman $(\%)$ & 13,95 & 13,93 & 14,32 & 14,07 \\
\hline 6 & Bobot 100 butir $(\mathrm{g})$ & 54,25 & 54,05 & 54,15 & 54,15 \\
\hline 7 & Bobot polong isi/tanaman & 98,05 & 99,71 & 108,16 & 101,97 \\
\hline 8 & Bobot polong isi/petak $\left(\mathrm{g} / 22,68 \mathrm{~m}^{2}\right)$ & 2647,23 & 2692,25 & 2043,47 & 2460,98 \\
\hline 9 & Hasil (t/ha) & 1,167 & 1,187 & 0,901 & 1,085 \\
\hline 10 & Populasi kacang tanah & 100 & 100 & 56 & 85 \\
\hline
\end{tabular}

Keterangan: *) Ukuran petak contoh 5,4 $\mathrm{m} \times 4,2 \mathrm{~m}\left(22,68 \mathrm{~m}^{2}\right)$

Tabel 5. Rataan komponen pertumbuhan, komponen hasil, dan hasil tanaman kacang hijau (tanaman urutan II) pada berbagai pola tanam berbasis padi gogo, Maluku Tenggara Barat, MK 2017

\begin{tabular}{clc}
\hline No & \multicolumn{1}{c}{ Parameter Tanaman Kacang Hijau } & Pola D \\
\hline 1 & Persentase Tumbuh $(\%)$ & 92,65 \\
2 & Tinggi Tanaman $(\mathrm{cm})$ & 62,80 \\
3 & Panjang Polong $(\mathrm{cm})$ & 10,72 \\
4 & Jumlah polong berisi per tanaman & 56,90 \\
5 & Persentase polong Hampa per Tanaman & 7,03 \\
6 & Bobot 100 butir $(\mathrm{g})$ & 6,20 \\
7 & Bobot biji ber nas tanaman $(\mathrm{g})$ & 15,46 \\
8 & Bobot biji ber nas/petak contoh $\left(\mathrm{g} / 22,68 \mathrm{~m}^{2}\right)^{*}$ & 3041,39 \\
9 & Hasil biji kering per hektar $(\mathrm{t} / \mathrm{ha})$ & 1,341 \\
10 & Populasi tanaman Kacang Hijau & 56 \\
\hline
\end{tabular}

Keterangan: *) Ukuran petak contoh 5,4 $\mathrm{m} \times 4,2 \mathrm{~m}\left(22,68 \mathrm{~m}^{2}\right)$ 
Tabel 6. Rataan komponen pertumbuhan, komponen hasil, dan hasil ubikayu tanaman (Urutan I) pada berbagai pola usahatani berbasis padi gogo, Maluku Tenggara Barat, MK 2017

\begin{tabular}{clc}
\hline No & \multicolumn{1}{c}{ Parameter Ubi Kayu } & Pola-D \\
\hline 1 & Persentase tumbuh $(\%)$ & 100 \\
2 & Tinggi Tanaman $(\mathrm{cm})$ & 257,50 \\
3 & Umur Panen (bulan) & 10 \\
4 & Panjang Umbi di jual $(\mathrm{cm})$ & 41,00 \\
5 & Diameter Umbi $(\mathrm{cm})$ & 8,10 \\
6 & Jumlah Umbi di jual per Tanaman & 20,20 \\
7 & Persentase Umbi kecil $(\%)$ & 17,72 \\
8 & Bobot Umbi segar per tanaman & 1371,67 \\
9 & Bobot Umbi segar per petak contoh $\left(\mathrm{g} / 22,68 \mathrm{~m}^{2}\right)$ & 13168,01 \\
10 & Hasil umbi segar/ha & 5,806 \\
11 & Populasi Tanaman Ubi Kayu $(\%)$ & 48 \\
\hline
\end{tabular}

Keterangan: Ukuran Petak Contoh 5,4 m × 4,2 m (22,68 m²)

Peubah pertumbuhan, komponen hasil dan hasil tanaman kacang hijau sebagai tanaman urutan II (PolaD) yang diamati meliputi tinggi tanaman, panjang dan jumlah polong berisi per tanaman, persentase polong hampa, bobot 100 butir, bobot biji bernas per (tanaman dan petak ubinan) dan hasil biji kering per hektar, tersaji pada Tabel 5. Varietas kacang hijau yang digunakan adalah Vima-1 kelas benih FS (benih pokok), memiliki tinggi tanamam $53 \mathrm{~cm}$, polong masak berwarna hitam, umur panen $80 \% 57$ hari, bobot 100 biji $6,3 \mathrm{~g}$, dan potensi hasil 1,76 t/ha (Balitkabi, 2008).

Kacang hijau sebagai tanaman urutan II padaa pola tanam berbasis padi gogo (Pola D), memiliki persentase tumbuh cukup baik (92.65\%), umur cenderung lebih tinggi $(62,8 \mathrm{~cm})$, bobot 100 biji $(6,2 \mathrm{~g})$ dan hasil yang dicapai $(1,341 \mathrm{~g})$ cenderung lebih rendah dibandingkan dengan deskripsinya (Tabel 5). Hal ini disebabkan karena kacang hijau ditanam diantara ubikayu setelah panen padi gogo dan jagung, sehingga pertumbuhan tanaman mengalami etiolasi, yaitu tanaman tumbuh cendrung lebih tinggi. Menurut Taiz dan Zeiger (1991) tanaman pada perlakuan naungan mengalami proses etiolasi sehingga pertumbuhan tanaman lebih tinggi, begitu juga dengan luas daun, dimana pada tanaman muda terjadi peningkatan luas daun dengan bertambahnya taraf naungan.

\section{e. Keragaan Pertumbuhan, Komponen Hasil, dan Hasil Tanaman Ubikayu Tanaman Urutan I)}

Tanaman ubikayu ditanam secara tumpangsari merupakan tanaman sisipan, yaitu tanaman sisipan diantara barisan jagung setiap dua tanaman jagung pada Pola $\mathrm{D}=$ Pola Tanam Introduksi (Padi Gogo + Jagung/Ubikayu - Kacang Hijau - Kacang Tanah, yaitu padi gogo ditumpangsarikan dengan jagung, tiga minggu kemudian tanaman ubikayu disisipkan didalam barisan jagung setiap dua tanaman jagung, setelah padi gogo dan jagung dipanen diikuti kacang tanah, dan setelah kacang tanah dipanen diikuti kacang hijau.

Jenis ubi kayu yang digunakan adalah varietas unggul lokal (Kasbi Nasi), tidak bercabang, berumur 10 bulan, rata-rata hasil yang dicapai ditingkat petani 13,48 t/ha (BPS MTB, 2016).

Peubah yang diamati meliputi persentase tumbuh, tinggi tanaman, panjang umbi dan diameter umbi yang dijual, perentase umbi kecil, bobot umbi segar per (tanaman dan petak ubinan), serta hasil umbi segar per hektar, tersaji pada Tabel 6. Tabel 6 menunjukkan bahwa tanaman ubikayu yang ditanam secara tumpangsari (sisipan) pada Pola D, memiliki persentase tumbuh cukup baik (100\%), tinggi tanaman $257,50 \mathrm{~cm}$, umur panen 10 bulan, persentase umbi kecil $17,72 \%$ dan hasil umbi segar yang dicapai 5.806 t/ha. Rendahnya hasil ubikayu ini, disebabkan karena populasi tanaman adalah rendah $(48 \%)$.

\section{KESIMPULAN}

Penanaman padi gogo secara tumpangsari dan tumpanggilir, yaitu Pola Tanam Petani Perbaikan (Padi Gogo + Jagung - Kacang Hijau) dan Pola Tanam Introduksi (Padi Gogo + Jagung/Ubikayu - Kacang Hijau - Kacang Tanah) dapat meningkatkan produktivitas lahan sebesar berturut-turut $135 \%$ dan $180 \%$, dibandingkan jika ditanam secara monokultur (Pola Petani-A dan Pola Petani-B).

Pola bertanam ganda (tumpangsari/tumpanggilir/ tanaman sisipan) dapat direkomen-dasikan sebagai pola tanam berbasis padi gogo dilahan kering karena dapat meningkatkan produktivitas lahan $>100 \%($ IPG $=135$ $\%-180 \%)$

\section{UCAPAN TERIMA KASIH}

Kami mengucapkan terima kasih kepada Peneliti Senior Lembaga Pengkajian Teknologi Pertanian Maluku, Dr. Ir. Janes Berthy Alfons, M.S untuk bimbingan dan implementasi lapangan kegiatan Pola Tanam Berbasis Padi Gogo Pada Lahan Kering di Maluku. Kami juga mengucapkan terima kasih kepada semua pihak di bidang implementasi kegiatan yang telah membantu sehingga penelitian ini dapat dilakukan 
dengan baik. Tidak lupa mengucapkan terima kasih kepada semua pejabat Badan Penelitian dan Pengembangan Pertanian, Kementerian Pertanian atas alokasi penilaian biaya untuk dialokasi ke Maluku dalam upaya mendukung ketersediaan pangan.

\section{DAFTAR PUSTAKA}

Arifin, Z. dan H.M. Toha. 1996. Perbaikan pola tanam tanaman pangan untuk meningkatkan produktivitas lahan kering. Jurnal Penelitian Pertanian 15: 174-180.

Badan Litbang Pertanian. 2005. Panduan Pengkajian dan Diseminasi Hasil Pengkajian. Badan Penelitian dan Pengembangan Pertanian. Departemen Pertanian.

[BPS Promal] Badan Pusat Statistik Maluku. 2016. Maluku Dalam Angka 2015. Ambon: Badan Pusat Statistik Provinsi Maluku.

[BPS MTB] Badan Pusat Statistik Maluku Tenggara Barat. 2016. Maluku Tenggara Barat Dalam Angka 2015. Badan Pusat Statistik Kabupaten Maluku Tenggara Barat.

[Balitkabi] Balai Penelitian Kacang-Kacang dan UmbiUmbian. 2008. Deskripsi Varietas Unggul: Kacang-Kacangan dan Umbi-Umbian. Balitkabi, Badan Litbang Pertanian, Deptan.

Bunyamin, Z. dan Awaluddin. 2013. Pengaruh Populasi Tanaman Terhadap Pertumbuhan dan Hasil Jagung Semi (Baby Corn). Prosiding Seminar Nasional Serealia, Meningkatkan Peran Penelitian Serealia Menuju Pertanian Bioindustri, Maros 18 Juni 2013. Hal: 214-219.

[CRIFC] Central Research Institute for Food Crops. 1996. Indonesian Farming System Research and development, the Food Crops Subsystem. Agency for Agricultural Research and Development, Central Research Institute for Food Crops. 131 p.

Fagi, A.M., H.M. Toha, dan J.S. Baharsyah. 2004. Potensi Padi Gogo Dalam Swasembada Beras. Dalam: Kasryno, F., E. Pasandaran, dan A.M. Fagi (Eds.). Ekonomi Padi dan Beras Indonesia. Badan Penelitiandan Pengembangan Pertanian. Jakarta. pp. 347-372.

Fitria, E. dan M.N. Ali. 2014. Kelayakan usahatani padi gogo dengan pola pengelolaan tanaman terpadu (PTT) di Kabupaten Aceh Besar, Provinsi Aceh. Widyariset 17: 425-434.

Gomez, K.A., dan A.A. Gomez. 1995. Prosedur statistic untuk Pertanian (edisi ke-2). Sjamsuddin, E., J.S. Barharsjah, penerjemah. Jakarta: Penerbit Universitas Indonesia (UI-Press).

Hairmansis, A., Yullianida, Supartopo, dan Suwarno. 2016. Pemuliaan padi gogo adaptif pada lahan kering. Iptek Tanaman Pangan 11: 95-106.

Hasfiah, M. Taufik, dan T. Wijayanto. 2012. Uji daya hasil dan ketahanan padi gogo lokal terhadap penyakit blas (Pyricularia oryzae) pada berbagai dosis pemupukan. Berkala Penelitian Agronomi 1: $26-36$

Idawanni, Hasanuddin, dan Bakhtiar. 2016. Uji adaptasi beberapa varietas padi gogo di antara tanaman kelapa sawit muda di Kabupaten Aceh Timur. Jurnal Floratek 11: 88-95.

Nazirah, dan B.S.J. Damanik. 2015. Pertumbuhan dan hasil tiga varietas padi gogo pada perlakuan pemupukan. Jurnal Floratek 10: 54-60.

Sugiantari, N.P.N., I.G.N. Raka, dan Utami. 2017. Uji mutu benih kedelai (Glycine max L. Merril) varietas grobogan yang diproduksi dengan aplikasi 10 isolat PGPR. AGROTROP 7: 199-209. DOI: 10.24843/AJoAS.2017.v07.i02.p11

Palaniappan, S.P. 1985. Cropping System in the Tropics. Principles and Management. Wiley Easterm Limited and Tamil Nadul Agricultural University Combatore, India.

Permanasari, I. dan D. Kastono. 2012. Pertumbuhan tumpangsari jagung dan kedelai pada perbedaan waktu tanam dan pemangkasan jagung. Jurnal Agroteknologi 3: $13-20 . \quad$ DOI: 10.24014/ja.v3i1.90

Siagian, M.H. dan R. Harahap. 2001. Pengaruh Pemupukan dan Populasi Tanaman Jagung Terhadap Produksi Baby Corn Pada Tanah Podsolik Merah Kuning. Puslitbang Biologi. LIPI - Bogor.

Sumarno, dan J.R. Hidayat. 2007. Perluasan areal padi gogo sebagai pilihan untuk mendukung ketahanan pangan nasional. Iptek Tanaman Pangan 2: 2640.

Susanto, A.N. dan S. Bustaman. 2006. Data dan informasi Sumberdaya Lahan untuk Mendukung Pengembangan Agribisnis Di Wilayah Kepulauan Provinsi Maluku. Ambon: Balai Pengkajian Teknologi Pertanian Maluku, Badan Litbang Pertanian. 73 hal.

Taiz, L. and E. Zeiger. 1991. Plant Physiology. The Benyamin/Cumming Publishing Company Inc. p: 219-247.

Tamburian, Y. 2012. Kajian adaptasi varietas unggul baru jagung diantara pertanaman kelapa di Kabupaten Minahasa Selatan, Provinsi Sulawesi Utara. Buletin Palma 13: 32-40. DOI: 10.21082/bp.v13n1.2012.32-40

Toha, H.M. 2012. Pengembangan padi gogo mengatasi rawan pangan wilayah marginal. Dalam: Dariah A., B. Kartiwa, N. Sutrisno, K. Suradisastra, M. Sarwani, H. Soeparno, dan E. Pasandaran (Eds.). Prospek Pertanian Lahan Kering dalam Mendukung Ketahanan Pangan. Balitbangtan. Jakarta. p.143-163.

Toha, H.M., K. Pirngadi, K. Permadi, dan A.M. Fagi. 2009. Meningkatkan dan memantapkan produktivitas danproduksi padi gogo. Dalam: Daradjat, A.A., A. Setyono, A.K. Makarim, dan 
A. Hasanuddin (Eds.). Padi InovasiTenologi Produksi Buku 2. LIPI Press. Jakarta.

Wahdah.R, T. Susanto, dan M. Sodiq. 2012. Observasi beberapa karakter padi gogo lokal varietas buyung di hulu sungai tengah Kalimantan Selatan. Jurnal Agroscientiae 19: 100-106.

Wang, L.X. and J. Li. 2003. Crop Cultivation. Science Press, Beijing. (in Chinese).
Wendi, Gusmiatun, dan N. Amir. 2014. Evaluasi pertumbuhan dan produksi beberapa padi gogo (Oryza sativa L.) varietas Jati Luhur dan Situ Bagendit pada perbedaan jumlah benih yang ditanam. Klorofil 9: 94-99. DOI: 10.32502/jk.v9i2.119 